\title{
Chilled boneless beef international trade: a cluster analysis
}

\author{
Paulo Rodrigo Ramos Xavier Pereira ${ }^{1,2}$, Júlio Otávio Jardim Barcellos ${ }^{1,2,3,4}$, Roberta Dalla Porta \\ Gründling ${ }^{1,2}$, Maria Eugênia Andrighetto Canozzi ${ }^{2,3}$, Concepta McManus ${ }^{2,3}$, \\ Rúbia Branco Lopes ${ }^{2,5}$
}

\author{
1 Programa de Pós-Graduação em Agronegócios - CEPAN (UFRGS). \\ ${ }^{2}$ Núcleo de Estudos em Sistemas de Produção de Bovinos de Corte e Cadeia Produtiva - NESPRO (UFRGS). \\ ${ }^{3}$ Programa de Pós-Graduação em Zootecnia (UFRGS). \\ ${ }^{4}$ CNPq Productivity Researcher. Fellowship granted by CAPES/BRASIL, no. 2842/2010. \\ ${ }^{5}$ Acadêmica do Curso de Agronomia (UFRGS).
}

\begin{abstract}
The objective of this study was to measure and classify the international beef trade. For this, data related to the international chilled boneless beef (CBB) trade, the major and most important market, were analyzed. Producing countries were classified into groups according to their trade relations, and the main factors that influenced one country to prefer to import CBB from a specific exporting country were analyzed. The results revealed four markets related to client demands with regard to the sanitation and traceability of beef products. Furthermore, extrinsic characteristics of the product are discussed, such as a productive system that aims to minimize environmental impacts and to value animal welfare and respect for social demands. The markets that pay highest prices require sanitary quality of suppliers, demanding traceable and process-certified products. Brazil does not access these markets because it does not meet these requirements. To change this scenario it is necessary to eradicate FMD across the Brazilian territory, acquiring a status of a zone with minimal BSE risk, aligning the intrinsic value of the $\mathrm{CBB}$ with expectations of consumers and implementing a traceability program that is both feasible and acceptable for clients.
\end{abstract}

Key Words: animal health, beef exports, Brazil, traceability

\section{Introduction}

The international beef trade expansion after the establishment of the World Trade Organization (WTO) has provided new opportunities for countries that are beef producers. The productive chains (PC) attempt to meet consumer preferences. Among products originating from these PC, chilled boneless beef (CBB) has a relatively high price and trade volume, and also causes controversy within the international beef trade. Even though Brazil has benefited from global beef trade expansion, its market share has not reached its potential because it does not meet some demand requirements (DESA/UNSD, 2008).

In the Brazilian beef exports list, chilled beef represented $45 \%$ of invoices in fresh boneless beef world exports. This can be explained by the fact that its average price is about $50 \%$ more than frozen boneless beef. This higher price may be due to various factors, including the consumer preference for acquiring a product for which characteristics such as color and consistency are important (Barcellos, 2007).

In addition to these considerations, chilled beef shows a higher potential of zoonosis transmission and a higher likelihood to rot compared with the frozen product. In spite of these issues, $\mathrm{CBB}$ has a high international trade increase; countries such as United States, Mexico, Canada, South Korea, Chile and the European Union (EU) are the main importers.

The EU was the most profitable market for Brazilian CBB. However, from the beginning of 2008 the EU suspended Brazilian CBB imports (European Union, 2008); during the first ten months of 2008 this resulted in a decrease in the export revenue of more than $60 \%$ compared with the same period in the previous year (ALICEWEB, 2008). Considering this scenario, the objective of this study is to measure and classify the international beef trade.

As specific objectives this paper intends to delineate the profile of major importers of $\mathrm{CBB}$, their behavioral pattern in the market and what motivates them to choose a particular supplier, generating subsidies to discuss what are the key factors that are limiting the Brazilian competitiveness in international trade.

\section{Material and Methods}

The data used in the analysis was obtained from DESA/UNSD, which is the database for commodity trade 
in the United Nations. The export, import, and reimport records for hundreds of commodities of various orders, which consist of commercial partners, volumes, and values in American dollars (US\$) Free on Board (FOB) for transactions reported by nearly 200 countries are available in this guide. The variable used in this article was CBB, which was registered in the database under the code 020130 and classification HS 1992.

The 10 beef exporting countries with the highest prevalence in the annual classification of the United States Department of Agriculture (USDA) were selected for the sample. The exports of these 9 countries and 1 economic block (due to Common Agricultural Politics (CAP), EU-15 was considered as one country for both export and import) corresponded to $95.86 \%$ of the total metric tons of exported beef (Table 1). As importers, all countries that made FBB negotiations with the ten countries classified as exporters were considered.

Data collection and processing resulted in the following six variables:

Observation period or year (YEAR): the sample corresponded to FBB exports between 1994 and 2006; Exporting Country (EC): the ten main exporters (Table 1); Importing Country (IC): countries that imported FBB from one or more of the ten exporting countries that compose the sample; Traded Volume (TV): the total exported and imported between two commercial partners. Information originally expressed in $\mathrm{kg}$ and converted to tons; Invoicing (IV): total obtained in the commercial operation stated above, originally expressed in US\$ and converted into thousands of US\$ (1,000 US\$). Aiming to eliminate an inflation effect, the values were deflated using the Producer Price Index (BLS, 2008); Prices in US\$ per tons (P\$T):

Table 1 - Share of the main beef exporters in international trade (1994-2007)

\begin{tabular}{lc}
\hline Country & $\%$ \\
\hline Australia & 21.34 \\
Brazil & 15.70 \\
United States of America & 13.72 \\
European Union-15 (EU-15)* & 10.17 \\
New Zealand & 8.59 \\
Canada & 7.51 \\
Argentina & 7.30 \\
India & 6.08 \\
Uruguay & 4.33 \\
China & 1.12 \\
Subtotal & 95.86 \\
Other countries & 4.14 \\
Total & 100 \\
\hline
\end{tabular}

Compiled by authors from USDA (2007) data.

* For all observations, the 15 (fifteen) countries that constituted the European Union (EU) in 1995 were considered in the present research. average or absolute prices obtained per tons for each commercial operation.

A sample adjustment was performed eliminating the observations in which the volume was lower than the maximum capacity of an 18 metric ton container (ISO, 2008) and the deflation of values in dollars was carried out using Producer Price Index (BLS, 2008) as of January, 2007. This procedure reduced the number of observations from 3,198 to 2,404 and the total transacted volume by $0.05 \%$. Due to the high correlation between traded volume and invoicing, and because of compatibility between the aspects to be discussed in the results, only trade volume was used. This option is supported by a previous analysis done by the authors when running the application, showing no difference between using one variable or another.

The collected data were analyzed through variable grouping by similarity, also known as the cluster analysis statistical method. According to Hair et al. (1998), cluster analysis is a technique for classifying objects in groups that show internally homogeneous and heterogeneous characteristics relative to one another. This allows the researcher to identify group profiles in the observed population.

The main techniques employed in group classifications based on a data set are known as hierarchic and nonhierarchic methods (Hair et al., 1998), and the main difference between the two techniques is that the number of desired groups must be previously established at the nonhierarchic level. On the other hand, the groups classified through hierarchic techniques are a result of the available data (Mingoti, 2005).

The beef trade was evaluated in early studies through data grouping, leading to important information concerning consumer habits and preferences, such as the frequency and place of purchase, trends of consumption for a product type, origin and quality, and consciousness regarding nutritional and sanitary values (Bernues et al., 2003; McCarthy \& Henson, 2005; Oliver et al., 2006; McCarthy et al., 2007; Schnettler et al., 2008a).

All analyses were performed with the statistical software SPSS (Statistical Package for the Social Sciences, version 13.0) for Windows. The procedures consisted of descriptive data analysis, identification of co-linearity, and data processing through the algorithm Twosteps ${ }^{\circledR}$, which is designed for large groups of data with categorical and numerical variables (SPSS, version 13.0).

The Twosteps algorithm classifies clusters in a hierarchic pattern. The first step consists of a one-by-one evaluation of the data, allocating the observations into pre-formed clusters. Alternatively, a new group is created 
according to the logarithmical distance. In the second step, the initial groups are refined, with the aim of increasing the distance and forming a number of homogeneous groups as small as possible (SPSS, version 13.0). This algorithm is recommended for analyzing large amounts of data with categorical and numerical variables, such as the variables used in the present study.

Data processing through the Twosteps algorithm was performed by allocating categories such as YEAR, Exporting Country and Importing Country to the space reserved for categorical variables, and Traded Volume and Price in US\$ per tons to the space reserved for continuous variables. Algorithm execution gave rise to four clusters, which were named OCEANIA, AUS-NAFTA, EURASIA and SOUTHERN CONE. Regressions, mean differentiation tests and descriptive analysis of variables were also performed.

Finally, the data analysis and mining program SPHINX (SPHINX, version 5.0) was used, wherein data modeling grouped elements that did not contribute individually to at least $2 \%$ of the total traded volume into a cluster named "Others". This program allowed for the analysis of individual and collective clusters and the development of charts and a variable distribution map. These charts and map make it possible to geographically visualize the proximity of such variables. The variable distribution map was built by crossing the charts corresponding to Exporting Country, Importing Country, Clusters and Price in US\$ per tons (the latter being stratified into three categories, in which a price interval corresponded to approximately $1 / 3$ of the sum of Traded Volume on the sample).

\section{Results and Discussion}

The growth in international CBB trade from 1994 to 2006 was approximately $80 \%$, and the traded volume over this period was more than 13 million tons invoiced at US\$ 59.4 billion. This increase is fundamentally due to growth in US, Mexico and EU-15 imports (Figure 1); these countries account for about half of global CBB imports. The increase in Mexican and North American imports was due to a higher growth in consumption as compared with production, whereas the growth in EU-15 imports was due to a decrease in production relative to consumption (USDA, 2007; FAOSTAT, 2008).

There were interruptions in the growth trajectories of the CBB market in 2001, 2003-2004 and 2006 (Figure 1). The 2001 decline is associated with the suspension of Argentine beef imports by the EU (European Union, 2001) and other countries due to concerns regarding foot and mouth disease
(FMD). In 2003, the reduction in international trade resulted from a decrease in US and Mexico beef imports from Canada due to an outbreak of Bovine Spongiform Encephalitis (BSE) in Canada that year. This illness also influenced the 2004 decline since this outbreak led 70 countries (USDA, 2004), including Japan, Mexico, Canada, and South Korea, to partially or totally suspend beef imports from the US.

The decline in 2006 appears to have been associated with an increased number of BSE outbreaks in Canada, which led the US to decrease its imports from Canada (USDA, 2007). In addition to this, that same year, the Argentinean government attempted to reduce domestic inflation by suspending part of its beef exports for 180 days (Argentina, 2006).

Of the ten exporters under analysis (Figure 2), nine are responsible for more than $99 \%$ of world trade in CBB, and of one hundred and sixty-four importers that emerged in this research, only eight are responsible for $90 \%$ of the international transactions of CBB.

Therefore, international $\mathrm{CBB}$ trade appears to be very concentrated. In addition to that, this market mainly includes exporters that produce $\mathrm{CBB}$ in excess of domestic consumption, while importers consume more than they can produce (USDA, 2007; FAOSTAT, 2008). The US and Canada are two exceptions to this rule.

The US has a deficit in production, which is $9 \%$ lower than consumption, and yet, it exports more CBB than it imports. However, the high import volume of low-value, frozen boneless beef compensates for this difference. Because of CBB, the North American positive commercial balance is about US\$ 517 million. Canadian production is approximately $22 \%$ higher than consumption, and its positive commercial balance is about US\$ 547 million per year, which corresponds to approximately 157 thousand tons.

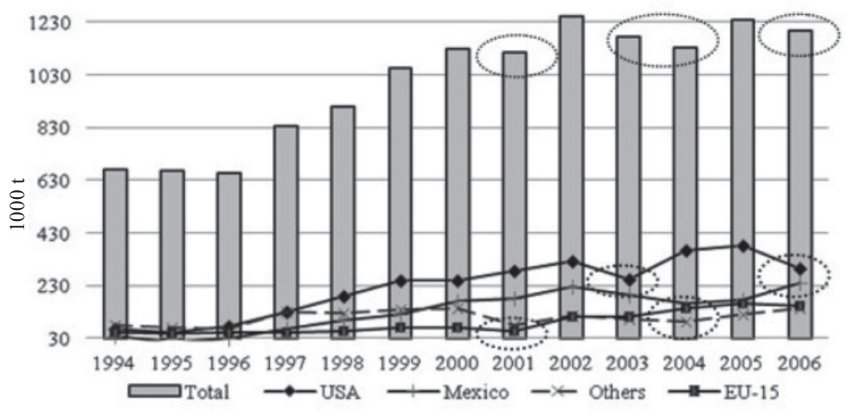

The circled areas at the top of the graph correspond to a decline in global imports, whereas the circles at the bottom of the graph indicate the country that most substantially negatively influenced trade that year.

Figure 1 - Traded volumes of the main importers of chilled boneless beef (1994-2006). 
The Eurasia cluster differs most from the overall sample mean on account of its high domestic prices that are also the lowest on the market (Figure 3). This characteristic is influenced by the profile of the customers from the cluster, which include those at the lowest level of economic development (World Bank, 2008a). Regarding India, this country is seen as risky for FMD outbreaks and as posing an unknown risk for BSE (WHO, 2007; WHO, 2008). It thus appears that the exporters for cluster are less focused on sanitary standards.

The Southern Cone cluster has higher prices than Eurasia but lower prices than others. Here, we can observe that this cluster possesses a few clients that are responsible for most imports. This is due to demand from the EU-15, which owing to a decrease in beef production (USDA, 2007) has been increasingly augmenting its imports from Brazil, Argentina and Uruguay. The prevalence of low, below-mean prices is due to low prices paid by Chile, which imports $40 \%$ of the CBB imported by this cluster.

Below the line separating the "hemispheres" are two clusters that concentrate most of their negotiations in monetary values surpassing the sample mean. These
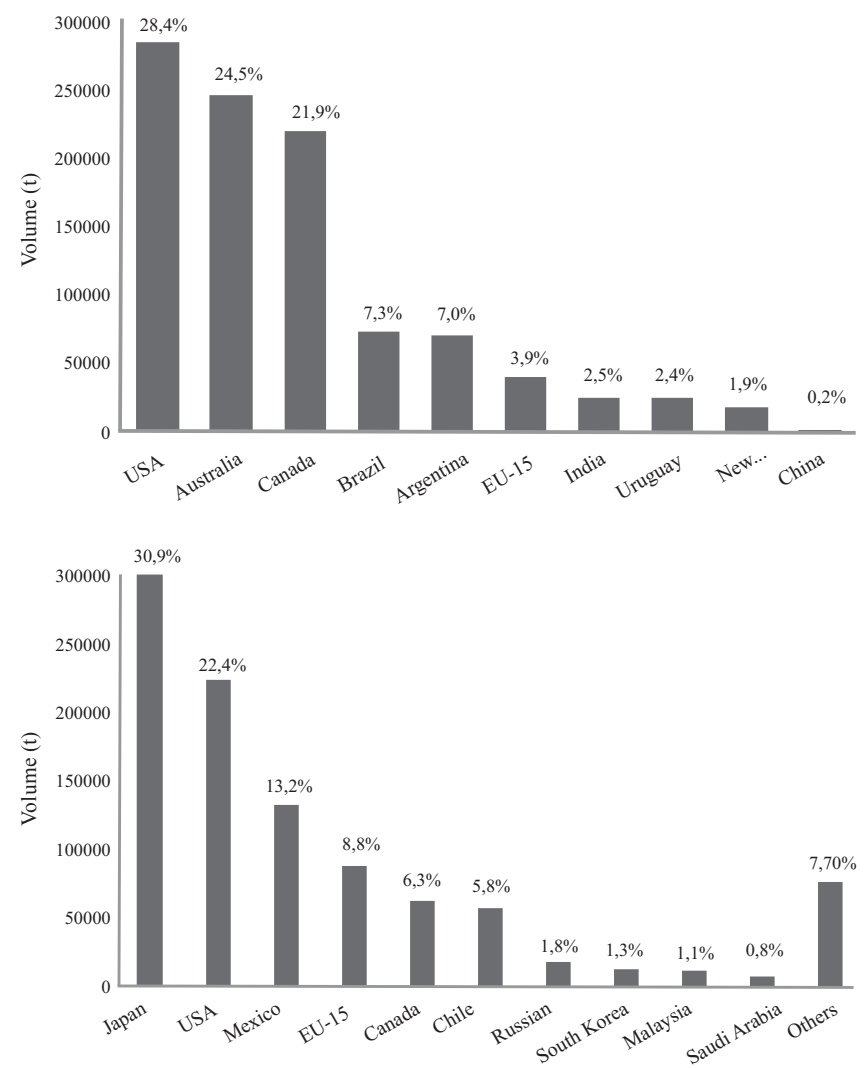

Figure 2 - Annual chilled boneless beef trade volume (t) and market share for the main exporters and importers (1994-2006). countries have a high level of economic development (World Bank, 2008a) and show the highest levels of sanitary conditions, certification and traceability with regard to their beef exports (Rich, 2005; Schwägele, 2005; Smith et al., 2005; Saghaian \& Reed, 2007; Jin \& Kim, 2008). These factors explain the higher prices of the Aus-NAFTA and Oceania clusters.

It is worth mentioning that the US, Mexico and Canada, all of which are part of the North American Free Trade Agreement (NAFTA), predominate the Aus-NAFTA cluster. Nevertheless, this alone does not maintain these trade relations, as BSE cases diagnosed in Canada and US in both 2003 and 2004 incited a severe decrease in trade between these countries (Sparling \& Caswell, 2006).

The Oceania Cluster includes two countries from Oceania, Australia and New Zealand, both of which are traditionally recognized as important beef producers. They

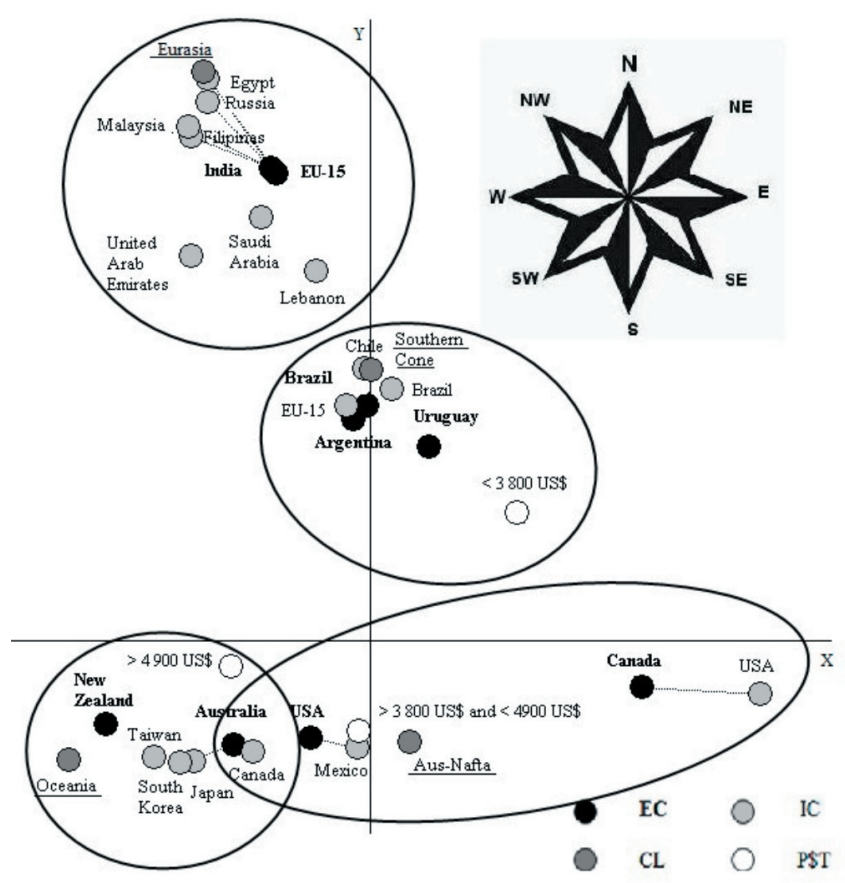

Note: the distance between variables represents the degree of prevalence in trade relations. That is, the shorter the distance between variables, the higher the relational degree between them. The lines that encircle variables are only illustrative, showing the concentration of the main agents in each cluster. In addition to it, the line that connects some agents shows that the transactional volume among them is higher than the expected value $(\mathrm{P}<0.05)$. The intersection of the axes represents the mean price of the sample, shaping quadrants where the top left limit corresponds to the minimum price, and the bottom left, to the maximum price observed. It is then understood that the negotiations performed at a price below the sample mean are placed on the north of intersectional axis, with the opposite applied to observations placed on the south of the intersectional point.

Figure 3 - Map generated through an algorithm from the software SPHINX, illustrating relationships between cluster (CL) variables exporting country (EC), importing country (IC) and price U\$T/t (P\$T) for frozen boneless beef international trade from 1994 to 2006. 
were classified by OIE as FMD-free countries that posed a low risk for BSE outbreaks (WHO, 2007; WHO, 2008). Ten countries import $87 \%$ of CBB from this cluster, such as North American countries and Asian ones (Table 2).

From 1994 to 2006, commercialization in this cluster increased by $290 \%$, and among the main customers, only Japan made no contribution to this growth, which reflects a decrease in its internal beef consumption. It is possible to verify a significant shift regarding US and Canada exports, which is interrupted only in 2003 with the appearance of BSE outbreaks in their territories (Figure 4). The aforementioned outbreaks led to a decline in exports and an increase in internal stocks, thereby reducing the need for imports.

The customers of this cluster are characterized by high incomes and high demands regarding the sanitary conditions of livestock (Rich, 2005), traceability (Schwägele, 2005; Smith et al., 2005) and process certification (Loureiro \&

Table 2 - Characteristics of the Oceania cluster (1994-2006)

\begin{tabular}{|c|c|c|c|}
\hline Exporters & TV/Annual & $\mathrm{P} \$ \mathrm{~T}$ & Cluster share $(\%)$ \\
\hline Australia & 46,291 & 5,190 & 71.3 \\
\hline New Zealand & 18,648 & 5,789 & 28.7 \\
\hline \multicolumn{4}{|l|}{ Importers } \\
\hline US & 21,921 & 4,609 & 33.8 \\
\hline South Korea & 7,537 & 5,269 & 11.6 \\
\hline EU-15 & 6,793 & 6,577 & 10.5 \\
\hline Japan & 4,902 & 6,218 & 7.6 \\
\hline Canada & 4,872 & 5,050 & 7.5 \\
\hline Taiwan $^{1}$ & 3,511 & 5,107 & 5.4 \\
\hline Hong Kong ${ }^{1}$ & 2,000 & 7,487 & 3.1 \\
\hline French Polynesia ${ }^{1}$ & 1,971 & 5,316 & 3.0 \\
\hline Singapore & 1,786 & 7,267 & 2.8 \\
\hline Indonesia & 1,383 & 5,487 & 2.1 \\
\hline Others & 8,264 & 5,239 & 12.7 \\
\hline Total & 64,939 & n.a. & 100.0 \\
\hline
\end{tabular}

Research results.

n.a. - not analyzed; TV - traded volume; P\$T - prices in US\$ per t.

Because of their differing political systems and economic and geographic characteristics, these three countries were analyzed separately from the other countries that make up this cluster (UN 2008).

Table 3 - Characteristics of the Aus-NAFTA cluster (1994-2006)

\begin{tabular}{lccc}
\hline Exporters & TV/Annual & P\$T & Cluster share (\%) \\
\hline US & 284,546 & 5,864 & 40.4 \\
Canada & 219,861 & 6,685 & 31.2 \\
Australia & 199,364 & 4,826 & 28.3 \\
Importers & & & \\
Japan & 304,687 & 6,117 & 43.3 \\
US & 195,759 & 3,557 & 27.8 \\
Mexico & 131,960 & 3,631 & 18.8 \\
Canada & 57,116 & 4,505 & 8.1 \\
Others & 14,248 & 6,274 & 2.0 \\
Total & 703,770 & n.a. & 100.0 \\
\hline
\end{tabular}

Research results.

n.a. = not analyzed; TV - traded volume; P\$T - prices in US\$ per $\mathrm{t}$.
Umberger, 2007). A typical example is the US, which imports only beef from countries that possess auditing systems and are recognized by the United States Department of Agriculture-Animal and the Plant Health Inspection Service (USDA-APHIS) (Rich, 2005; USDA, 2008). In general, these rules and regulations are aimed at preventing plagues and diseases in North American territory and preserving agricultural, economic, animal and human health.

South Korea and Japan only import beef from FMD-free countries and do not accept the sanitary system established by OIE (Rich, 2005). The trade relations preferentially occur with countries in which the production systems have safe and internationally-recognized sanitary controls, such as Australia and New Zealand.

In the Aus-NAFTA cluster, the US, Canada and Australia, all of which are countries traditionally recognized as important beef producers, are classified as exporters However, the two former countries have recorded BSE outbreaks, which have limited their access to markets in Japan, South Korea and Hong Kong. As importers, four clusters were identified and together they are responsible for $98 \%$ of the import volume from this cluster (Table 3). All of them are economically developed, FMD-free and, with the exception of Mexico, have recorded BSE outbreaks.

From 1994 to 2006, CBB trade within this cluster grew $53 \%$, which was attributed to an increase in the deficit between production and consumption that occurred in Mexico and the US (USDA, 2007). This fact is in part associated with the suspension in beef imports from Canada after its 2003 BSE outbreak (Mattson \& Koo, 2007). This disease was also responsible for a severe reduction in beef trade among members of NAFTA (Figure 5) as well as for the suspension of beef imports from the EU by Japan after the confirmation of the 2004 outbreak of the former.

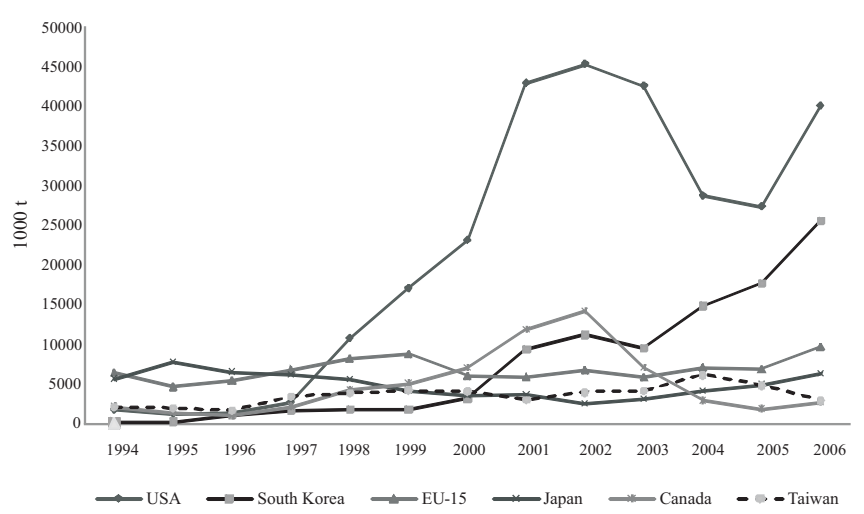

Figure 4 - Volume of chilled boneless beef commercialized by the main importers from the Oceania cluster (1994-2006). 
The data regarding CBB trade show a significant decline in exports from Canada and US after reports of disease. Nevertheless, the most relevant impact was the $71.5 \%$ decrease of American exports in 2004, which was associated mainly with the suspension of Japanese imports.

Within this cluster, imports from Japan began to decline in 2001 (Figure 5), associated with the fears consumers had of developing Creutzfeldt-Jakob disease (it is also related to BSE) by ingesting meat from infected animals. Research on beef consumer preferences in Japan verified fears related to the harmfulness of beef (McCluskey et al., 2005; Schroeder et al., 2007), and BSE has become a primary concern regarding the consumption of beef in Japan (Saghaian \& Reed, 2007).

After the BSE outbreaks in North America, Japan increased its imports originating from Australia and New Zealand, both of which are countries known by the OIE as posing insignificant risk for this illness. Moreover, the beef produced in New Zealand is considered to be a less harmful product by Japanese consumers. This popular conception even led one American fast food chain to develop a marketing campaign that emphasizes the fact that their hamburgers are made with Australian beef (McCluskey et al., 2005).

Japan has imposed restrictions on beef originated from countries with no significant BSE risk (USDA, 2007). To avoid acquiring beef from BSE carriers, Japan only imports from countries that have adopted practices such as BSE rapid testing in bovines older than 21 months, an identification system that traces beef information to its origin and a carcass classification system compatible with legal demands of Japan (Sugiura \& Smith, 2008).

The main importers within this cluster do not import fresh beef from markets with any status but "FMD-free country without vaccination" and are striving to fulfill

Table 4 - Characteristics of the Eurasia cluster (1994-2006)

\begin{tabular}{lccc}
\hline Exporters & TV/Annual & P\$T & Cluster share (\%) \\
\hline EU-15 & 39,439 & 4,941 & 61.4 \\
India & 24,826 & 1,261 & 38.6 \\
Importers & & & \\
Russia & 17,612 & 2,124 & 27.4 \\
Malaysia & 10,300 & 1,362 & 16.0 \\
Philippines & 6,657 & 3,457 & 10.4 \\
Egypt & 4,532 & 2,751 & 7.1 \\
Saudi Arabia & 4,348 & 2,397 & 6.8 \\
United Arab Emirates & 3,106 & 2,739 & 5.9 \\
Lebanon & 1,861 & 4,458 & 2.9 \\
Iran & 1,708 & 1,532 & 2.7 \\
Others & 14,142 & 3,619 & 20.9 \\
Total & 64,266 & n.a. & 100 \\
\hline
\end{tabular}

Research results.

n.a. - not analyzed; TV - traded volume; P\$T - prices in US\$ per t. the conditions established by the OIE and the SPS Agreement, which together enable the coexistence of two regions with different sanitary standards in the same country (Rich, 2005; Zepeda et al., 2005).

The preference of suppliers for high sanitary conditions is remarkable in this cluster since even among signatory countries of NAFTA, the diagnosis of a disease like BSE can interfere in trade relations and change beef trade flow, thereby benefiting competitors that garner the trust of consumers and are more prepared to address their demands.

In the cluster Eurasia, India and EU-15 are classified as exporters. This group differs from the other clusters, since India is a developing country with cattle-raising still expanding. However, its productive system still shows serious difficulties regarding productivity and sanity. Alternatively, the EU is a developed economy (World Bank, $2008 \mathrm{~b}$ ) and shows high indices of productivity in cattleraising. Moreover, the EU is under the FMD-free condition without vaccination and poses only a mild risk for BSE. Eight countries were identified as importers, which are collectively responsible for $78 \%$ of the traded volume within the cluster (Table 4). Almost all of these countries are in the Middle East, East Asia and Southwest Asia and have average to low economic development (World Bank, 2008a).

As mentioned before, the market share of Eurasia cluster is small and its prices are low. This is partially explained by the economic development of most of its members, since this is the only cluster in which importers of developed economies are not exclusively predominant (World Bank, 2008a).

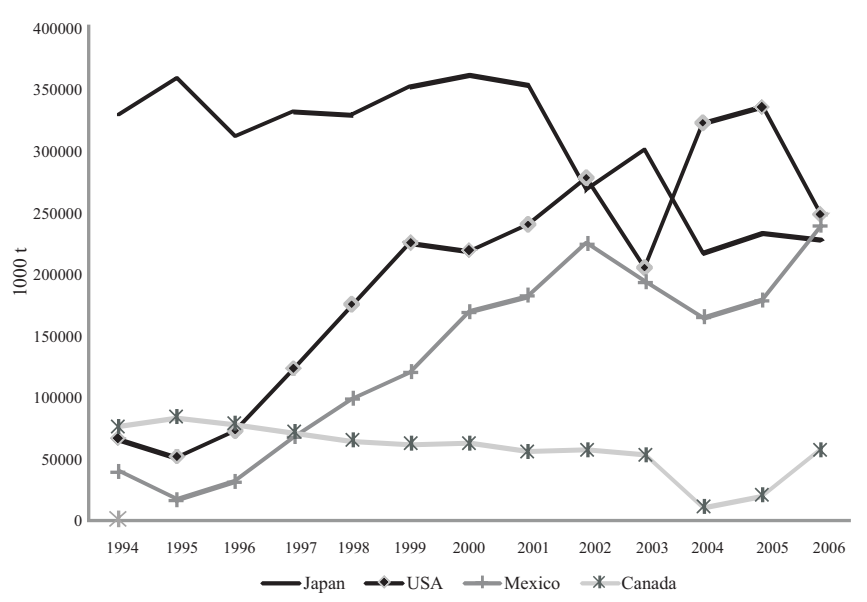

Figure 5 - Volume of chilled boneless beef traded by the main importers in the Aus-NAFTA cluster (1994-2006). 
Table 5 - Characteristics of the Southern Cone cluster (1994-2006)

\begin{tabular}{lccc}
\hline Exporters & TV/Annual & P\$T & Cluster share (\%) \\
\hline Argentina & 73,275 & $4,887 \mathrm{a}$ & 43.2 \\
Brazil & 69,971 & $3,319 \mathrm{bc}$ & 41.2 \\
Uruguay & 24,474 & $4,322 \mathrm{ab}$ & 14.4 \\
Importers & & & \\
EU-15 & 79,216 & $7,344 \mathrm{a}$ & 46.7 \\
Chile & 57,565 & $2,819 \mathrm{~d}$ & 33.9 \\
Brazil & 6,857 & $4,620 \mathrm{~b}$ & 4.0 \\
US & 6,410 & $3,858 \mathrm{c}$ & 3.8 \\
Lebanon & 4,488 & $3,177 \mathrm{~d}$ & 2.6 \\
Others & 15,176 & 3,787 & 8.9 \\
Total & 169,712 & n.a. & 100.0 \\
\hline
\end{tabular}

Research results.

Equal letters denote countries that are statistically similar to each other according to the Tukey test $(\mathrm{P}<0.05)$.

n.a. = not analysed; TV - traded volume; $\mathrm{P} \$ \mathrm{~T}$ - prices in US\$ per t.

Russia is a notable customer of this cluster (Segrillo, 2000). A substantial increase in Russian imports occurred in 2002 by the increased consumption and economic growth that was sustained in great part by an increase in petroleum exports (USDA, 2002; Basdevant \& Hall, 2002). Since 2003, trade transactions have been made almost exclusively between Russia and the EU-15, which explains interruptions in the imports from other importers (Figure 6).

Perhaps because there is sparse discussion of these countries within international $\mathrm{CBB}$ trade, there are few publications about importing countries from this cluster, which in turn makes it more difficult to discuss their trade characteristics in depth. However, based on an empirical analysis of the data collected, it appears that, with the exception of Russia, the negotiations of the major importers are made with India, which suggests a greater concern with prices rather than sanitary quality.

The Southern Cone cluster includes Argentina, Brazil and Uruguay as exporters. Each of these three South American countries has a grazing-based cattleraising production system that plays a key role in their respective economies. They are also characterized by recurrent outbreaks of FMD, the regionalization of sanitary standards (WHO, 2007) and no history of BSE outbreaks. They are countries in which cattle-raising has made distinct contributions to gross domestic product (GDP). Moreover, while they have different priorities in cattle-raising, all share a high level of beef consumption per capita. There are five principal clients, which together are responsible for $91 \%$ of imports within the cluster and have similar demands regarding CBB imports (Table 5).

From 1994 to 2006, the Southern Cone Cluster showed the second highest growth in the market, raising its involvement in the international CBB trade from $15 \%$ to $28 \%$ and increasing the amount of traded product from 72,400 t to $273,500 \mathrm{t}$. Since 2005 this volume has only declined twice, in 1998 and 2001. The first decline was related to a decrease in Chilean imports, and the second involved a decrease in imports from the EU-15. In both cases, the decline is attributed to Argentina. In $2001 \mathrm{CBB}$ exports from Argentina fell $80 \%$ due to concerns that FMD had infected cattle throughout the country; this led to a suspension in imports by EU, Chile and other customers (European Union, 2001).

A new reduction in imports occurred in 2006 and was again associated with Argentina because during that year the Economy and Production Ministry released a resolution that forbade beef exports for 180 days in order to control inflation, allowing only exports sanctioned by the Hilton Quota and bilateral agreements (Argentina, 2006).

The decline in Argentinean exports associated with an increase in $\mathrm{CBB}$ exports from Brazil allowed the latter to become the major exporter in this cluster (Figure 7). This increase in Brazilian beef exports started in 1999 and was encouraged through the adoption of a floating exchange

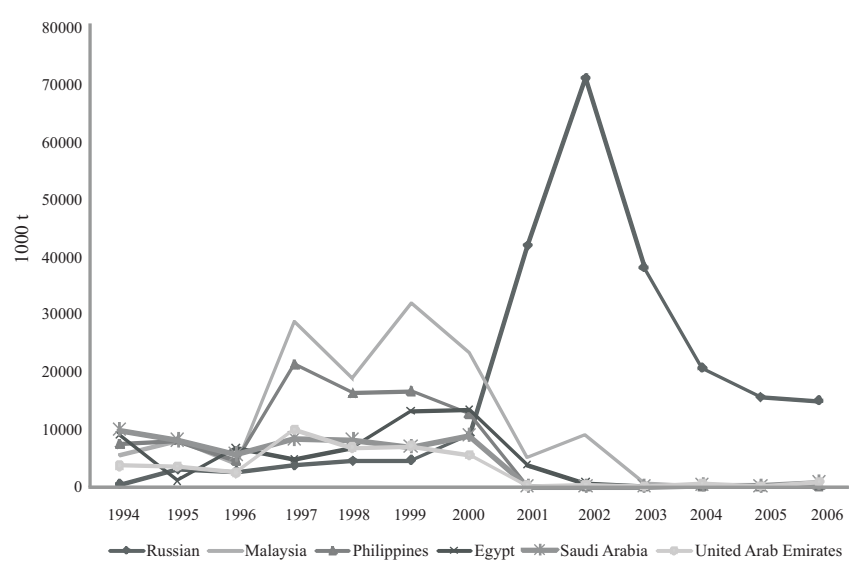

Figure 6 - Volume of chilled boneless beef traded by the main importers of the Eurasia cluster (1994-2006).

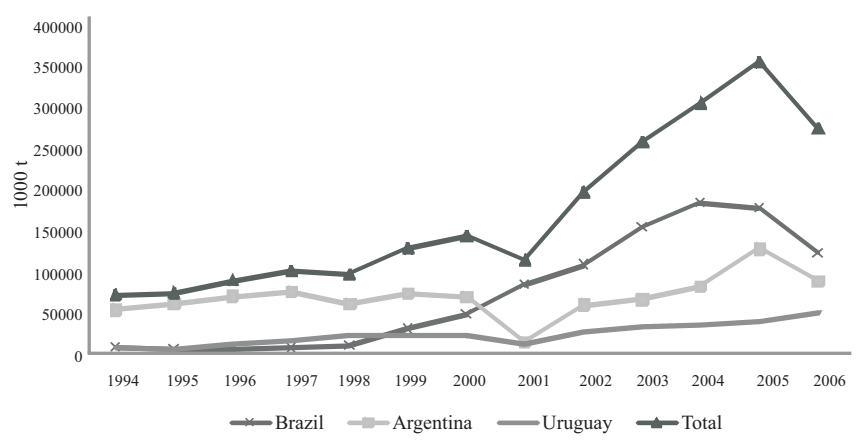

Figure 7 - Volume of chilled boneless beef traded from Southern Cone cluster exporters (1994-2006). 
policy that made Brazilian agricultural commodities more attractive to foreign consumers (Polaquini et al., 2006). However, it should be noted that although this change in exchange policy favored Brazilian CBB exports, this is only one of many aspects under discussion during beef trade negotiations. Factors such as traceability, reliability and sanity are regular concerns of more demanding clients that, in turn, pay the highest prices.

Chile and EU-15 monopolize imports within this cluster, being responsible for more than $80 \%$ of purchases (Figure 8). Of these two, EU-15 pays the highest prices: about $45 \%$ above the cluster average. Moreover, it is a market that serves as a reference point for many other markets and also demands the highest product volume.

In 1989, the EU cited risks to public health as it forbade beef imports from animals treated with growth hormones, excluding products originating from the US (Tonsor et al., 2005). It was also a pioneer in the bovine traceability system with resolutions EC 820/1997, EC 1760/2000 and EC 1825/2000 (European Union, 1997a; 2000a; 2000b), which require documentation of the entire life of each animal and specific criteria in beef and derivative labels.

These measures were motivated largely due to reports of BSE in the EU, which incited fears of consuming a product that would result in illness. In addition to that, there was also a qualm that the growth hormones used in bovines could pose health risks (Schwägele, 2005). The cluster responded to these issues by applying preventive sanitary measures, prohibiting the use of derivatives of bovine flour in ruminant ration and implementing bovine traceability. Moreover, currently there are other demands imposed by European consumers, such as concerns with animal welfare, social and economical equity, and environmental preservation (Bernues et al., 2003).

Another important development regarding the EU is the establishment of an importing quota with reduced fees. This quota is known as the Hilton Quota, and it allows certain countries, such as Argentina, Brazil, and Uruguay, to export prime beef cuts with specific patterns at a $20 \%$ ad valorem fee (European Union, 1997b); the amount that exceeds this quota is taxed at $12.8 \%+€ 3,040$ per ton (European Commission, 1999). The lower tariff should stimulate the exporting of the best cuts, and these two factors together would result in a higher price paid to the exporter (Bureau et al., 2005). Of the three exporters in this cluster, Brazil exhibits the smallest participation in the Hilton Quota (5,000 t), whereas Uruguay and Argentina trade 6,300 and 28,000 tons, respectively. Argentina was still benefiting from the Quota in 2002 and 2003 through a $10,000 \mathrm{t}$ additional quota.
The EU-15 is responsible for $46.9 \%$ of Brazilian exports, $52.2 \%$ of Argentine exports, and $34 \%$ of Uruguayan exports of CBB. Of these, $13.69,85.9$ and $75.5 \%$ correspond to the product traded under the Hilton Quota by Brazil, Argentina, and Uruguay, respectively. As the intra-quota product tends to reach a higher FOB price, part of the difference of the price paid to the three exporters in this cluster can be explained by this tariff measure (Figure 9). However, this explanation is only appropriate for Brazil and Uruguay, countries that have shown a significant increase of $67.6 \%$ and $15.4 \%$, respectively, due to the effect of the Hilton Quota on the price per CBB ton.

Chile is the second major importer in this cluster and remains among the countries that pay the lowest prices, which are around $30 \%$ below the cluster average and $61.1 \%$ lower than the EU-15. According to the data collected for the present study, the prices paid by Chile are not statistically

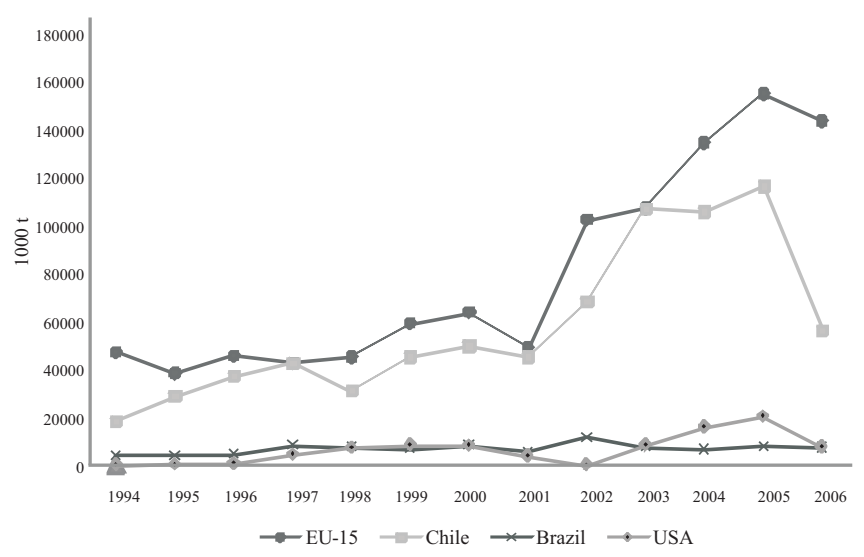

Figure 8 - Volume of chilled boneless beef traded by Southern Cone cluster importers (1994-2006).

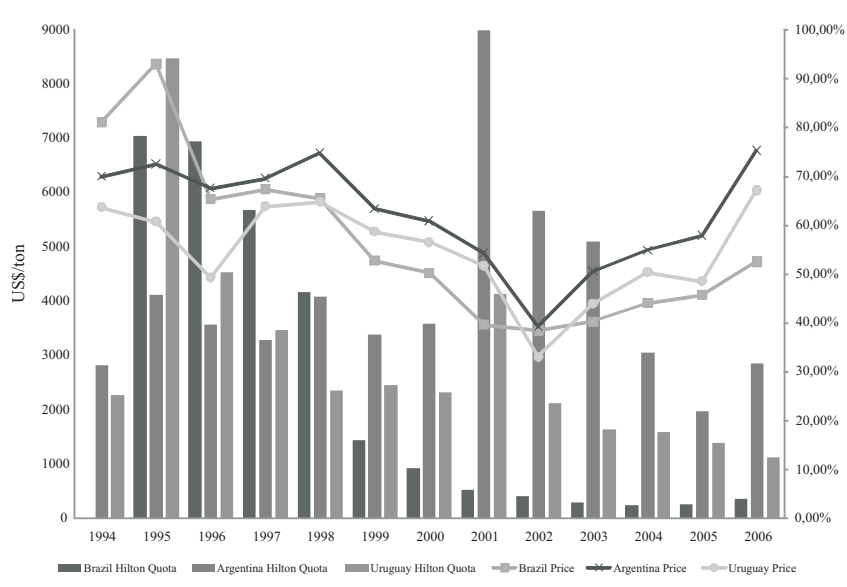

Figure 9 - Hilton Quota participation within the Southern Cone intra-cluster for volumes of chilled boneless beef exports and mean prices (1994-2006). 
different relative to the country of origin of the product; this conflicts with preferences of the consumer, who considers product origin to be more important than its price, especially for customers that value local and Argentinean beef and have unfavorable attitudes toward Brazilian beef (Schnettler et al., 2008a). These authors propose that the rejection of Brazilian beef may be related to intrinsic characteristics of the product, due to the predominance of Zebu cattle in the Brazilian production system, which has characteristics regarding tenderness and appearance different from those desired by Chilean consumers.

Chilean consumers also seem to value extrinsic factors, such as animal welfare and graze-feeding production. Mostly, these consumers consider these factors to be desirable and accept having to pay more for a product with such characteristics (Schnettler et al., 2008b). Thus, although prices within this cluster are below the market average, there is a clear preference by its main clients for acquiring beef from suppliers that have adopted OIE sanitary guidelines. Suppliers that fail to control diseases like FMD and BSE will invariably see negative effects on CBB imports.

As previously discussed, Brazil does not address all of the demands from the various countries that import CBB (Table 6).
Most requirements usually involve sanitary and traceability issues, but aspects related to extrinsic factors are important as well, such as minimizing environmental impact, animal welfare and respecting social demands. Brazilian production is not completely prepared to address most of these factors. Such deficiencies not only impact exports, they also reflect on the economic performance of rural producers and on the existence of other agents involved in bovine production that prevent the sustained development of this segment of agribusiness (CEPEA, 2008).

Brazil is aware of the various rules that guide international trade. Sanitary regulations illustrate this issue. Suspensions of Brazilian beef imports have repeatedly been implemented because of sanitary concerns (WHO, 2008; European Union, 2008); there have also been difficulties in establishing a bovine traceability program compatible with the demands of international importers.

Furthermore, the establishment of quotas, the application of tariffs on imports and the implementation of taxes reflect the performance of Brazilian exports (Montes \& Teixeira, 2007) and its narrowing access to more profitable markets. The same can be said with regard to the additional demands of some countries regarding issues such as animal welfare, environmental preservation and the determination of origin (Bernues et al., 2003;

Table 6 - Demands of the main importers of each cluster and the position of the Brazilian beef production

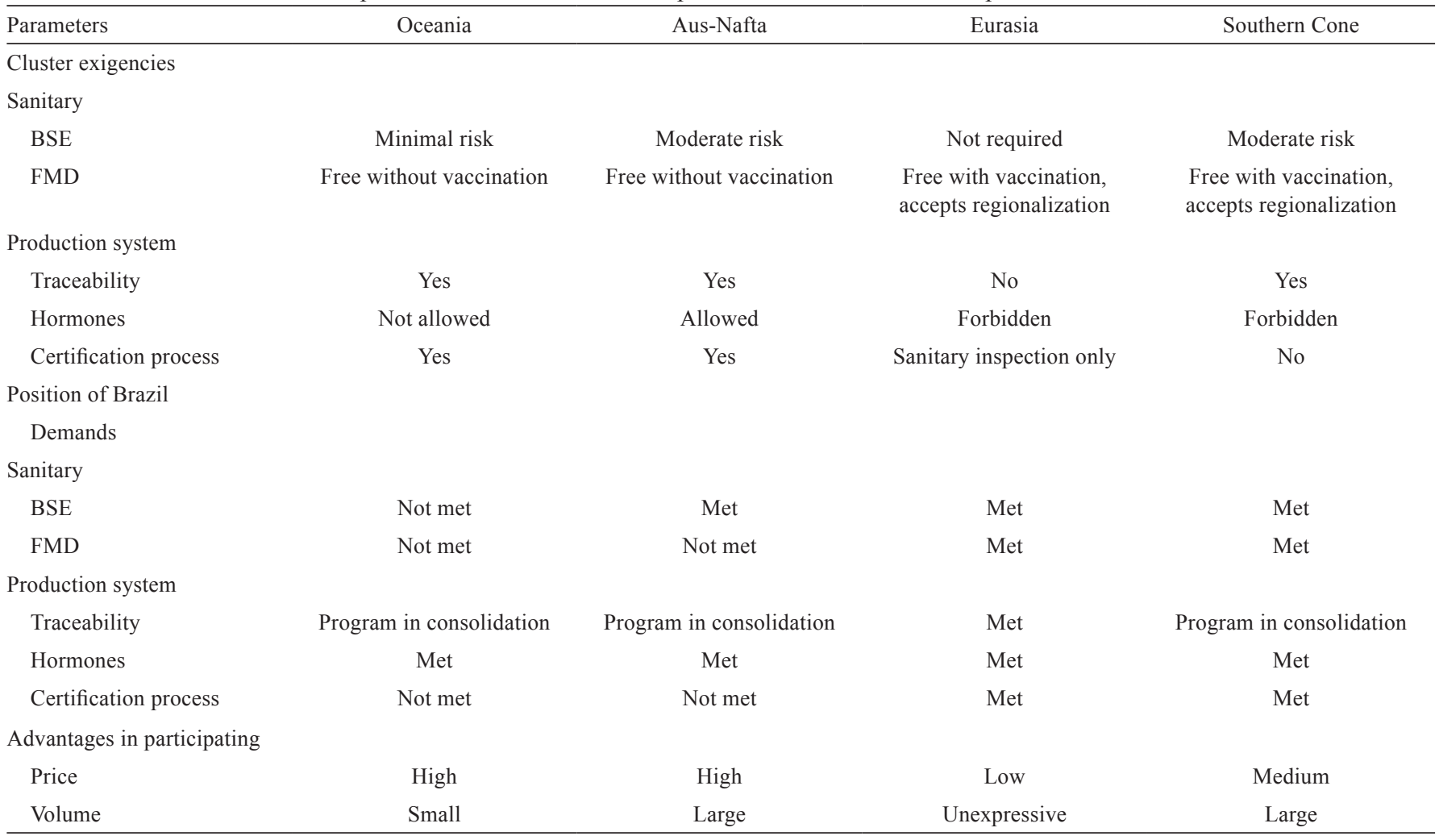

BSE - bovine spongiform encephalitis; FMD - foot and mouth disease. 
Schnettler et al., 2008a; Schnettler et al., 2008b). Moreover, aspects such as consumer preferences regarding the quality of food, habits, cultural and socio-demographic factors (Barcellos, 2007) and sanitary issues can also limit access to new markets (Sasaki \& Mitsumoto, 2004; Loureiro \& Umberger, 2007).

\section{Conclusions}

Four clusters representing the four markets that compose the international trade of chilled boneless beef were identified. These clusters were designed based on the demands of customers, which regard sanitary and traceability ambit, also emerging aspects related to extrinsic product factors, such as a productive system that cares for minimization of environmental impacts, animal welfare and respect to the social demands. The clusters that pay highest prices are Oceania and Aus-NAFTA, which value the sanitary quality of suppliers, demanding traceable and process-certified products. Currently, Brazil does not access these markets because it does not meet these requirements. To change it, strategies need to be established aiming at eradicating foot and mouth disease across the Brazilian territory, acquiring a status of a zone with minimal risk for Bovine Spongiform Encephalitis, aligning the intrinsic value of the chilled boneless beef with expectations of consumers and implementing a traceability program that is both feasible and acceptable for clients.

\section{References}

ALICEWEB. [2008] Análise de informações de comércio exterior via internet. Ministério do Desenvolvimento Indústria e Comércio. [2008]. Available at: <http://aliceweb.desenvolvimento.gov.br/> Accessed on: Apr. 15, 2008.

ARGENTINA. Secretaria Nacional de Sanidad y Calidad Agroalimentaria. [2006]. Resolución 114/2006. Available at: $<$ http://www.senasa.gov.ar/contenido.php?to=n\&in=1169\&ino $=1$ 169\&io=6269> Acessed on: Sept. 8, 2010.

BARCELLOS, M.D. "Beef lovers": um estudo cross-cultural sobre o comportamento de consumo da carne bovina. 2007. 329f. Tese (Doutorado em Agronegócios) - Centro de Estudos e Pesquisas em Agronegócios (CEPAN)/Universidade Federal do Rio Grande do Sul, Porto Alegre.

BASDEVANT, O.; HALL, S.G. The 1998 Russian crisis: could the exchange rate volatility have predicted it? Journal of Policy Modeling, v.24, p.151-168, 2002.

BERNUES, A.; OLAIZOLA, A.; CORCORAN, K. Extrinsic attributes of red meat as indicators of quality in Europe: an application for market segmentation. Food Quality Preference, v.14, p.265-276, 2003.

BUREAU OF LABOR STATISTICS - BLS. [2008]. Database, tables \& calculators by subject. Available at: <www.bls.gov/data/> Acessed on: Jul. 29, 2008.

BUREAU J.C.; RAMOS, M.P.; SALVATICI, L. Tariffs, TRQs and import composition: the case of beef trade between the EU and Mercosur. In: DUBLIN SEVENTH ANNUAL CONFERENCE, 17., 2005, Dublin. Anais... Dublin, 2005. (CD-ROM).
CENTRO DE ESTUDOS AVANÇADOS EM ECONOMIA APLICADA - CEPEA. [2008]. Índices regionais e nacionais de exportação do agronegócio. Available at: $<$ http://www.cepea. esalq.usp.br/macro/> Accessed on: Sept. 9, 2008.

EUROPEAN COMMISSION. [1999]. Taxation and customs union. Integrated community tariff. Available at: $<\mathrm{http}: / /$ ec.europa.eu/taxation_customs/dds/tarhome_en.htm $>$ Accessed on: Oct. 8, 2008.

EUROPEAN UNION. [1997a]. Council Regulation (EC) No 820/97 of 21 April 1997. Establishing a system for the identification and registration of bovine animals and regarding the labelling of beef and beef products. Available at: <http://faolex.fao.org/cgi-bin/ faolex.exe?rec_id $=010625 \&$ database $=$ faolex\&search_type $=$ link \& table $=$ result\&lang=eng\&format name=@ERALL $>$ Accessed on: Sept. 6, 2008.

EUROPEAN UNION. [1997b]. Commission Regulation (EC) No 936/97 of 27 May 1997. Opening and providing for the administration of tariff quotas for high-quality fresh, chilled and frozen beef and for frozen buffalo meat. Available at: <http://eur-lex.europa. eu/LexUriServ/site/en/consleg/1997/R/01997R0936-20060313en.pdf $>$ Accessed on: Sept. 7, 2008.

EUROPEAN UNION. [2000a]. Regulation (EC) No 1760/2000 of the European Parliament and of the Council of 17 July 2000. Establishing a system for the identification and registration of bovine animals and regarding the labeling of beef and beef products and repealing. Available at: <http://eur-lex.europa.eu/ LexUriServ/site/en/consleg/2000/R/02000R1760-20070101-en.pdf $>$ Accessed on: Sept. 5, 2008.

EUROPEAN UNION. [2000b]. Regulation (EC) No 1825/2000 of 25 August 2000. Laying down detailed rules for the application of Regulation (EC) No 1760/2000 of the European Parliament and of the Council as regards the labelling of beef and beef products. Available at: <http://eur-lex.europa.eu/LexUriServ/LexUriServ. do?uri=CELEX:32000R1825:EN:HTML> Accessed on: Sept. 5, 2008.

EUROPEAN UNION. [2001]. Commission Decision of 4 April 2001. Amending Decision 93/402/EEC concerning animal health conditions and veterinary certification for imports of fresh meat from South American countries to take account of the animal health situation in Argentina. Available at: <http://eur-lex.europa. $\mathrm{eu} /$ Notice.do mode $=\mathrm{db} 1 \&$ lang $=\mathrm{en} \& \mathrm{ihmlang}=\mathrm{en} \& \operatorname{lng} 1=\mathrm{en}$,en $\& \operatorname{lng} 2=$ da,de,el,en,es,fi,fr,it,nl,pt,sv, \&val $=259074$ : cs\&page $=>$ Accessed on: Sept. 7, 2008.

EUROPEAN UNION. [2008]. Commission Decision of 17 January 2008. Amending annex II to Council Decision 79/542/EEC as regards the imports of bovine fresh meat from Brazil. Available at: <http://eur-lex.europa.eu/LexUriServ/LexUriServ.do?uri=OJ: L:2008:015:0033:0035:en:pdf> Accessed on: Sept. 6, 2008.

FOOD AND AGRICULTURE ORGANIZATION OF THE UNITED NATIONS STATISTICS - FAOSTAT. [2008]. Trade. Available at: $<$ http://faostat.org/degault.aspx> Accessed on: June 9, 2008.

HAIR JR., J.F.; ANDERSON, E.; TATHAM, R.L. et al. Multivariate data analysis. 5.ed. New Jersey: Prentice Hall, 1998. 768p.

INTERNATIONAL ORGANIZATION FOR STANDARTIZATION - ISO. [2008]. Available at: <http://www.iso.org> Accessed on: Oct. 26, 2008.

JIN, H.J.; KIM, J.C. The effects of the BSE outbreak on the security values of US agribusiness and food processing firms. Applied Economics, v.40, p.357-372, 2008.

LOUREIRO, M.L.; UMBERGER, W.J. A choice experiment model for beef: What US consumer responses tell us about relative preferences for food safety, country-of-origin labeling and traceability. Food Policy, v.32, p.496-514, 2007.

MATTSON, J.W.; KOO, W.W. Effects of bovine spongiform encephalopathy outbreaks on US cattle and beef prices. Review of Agricultural Economics, v.29, p.734-748, 2007.

McCARTHY, M.; HENSON, S. Perceived risk and risk reduction strategies in the choice of beef by Irish consumers. Food Quality and Preference, v.16, p.435-445, 2005. 
McCARTHY, M.; BRENNAN, M.; KELLY, A.L. et al. Who is at risk and what do they know? Segmenting a population on their food safety knowledge. Food Quality and Preference, v.18, p.205-217, 2007.

McCLUSKEY, J.J.; GRIMSRUD, K.; OUCHI, H. et al. Bovine Spongiform Encephalopathy in Japan: consumers' food safety perceptions and willingness to pay for tested beef. Australian Journal of Agicultural and Resources Economics, v.49, p.197-209, 2005.

MINGOTI, S.A. Análise de dados através de métodos de estatística multivariada: uma abordagem aplicada. Belo Horizonte: UFMG, 2005. 300p.

MONTES, E.Z.; TEIXEIRA, E.C. Impactos da Área de Livre Comércio das Américas (Alca), com gradual desgravação tarifária, na economia brasileira. Revista Nova Economia, v.17, p.37-63, 2007.

OLIVER, M.A.; NUTE, G.R.; FONT I FORNOLS, M. et al. Eating quality of beef, from different production systems, assessed by German, Spanish and British consumers. Meat Science, v.74, p.435-442, 2006.

POLAQUINI, L.E.M.; DE SOUZA, J.G.; GEBARA, J.J. Changes in the Brazilian beef cattle production and commercialization system post-Mercosul. Revista Brasileira de Zootecnia, v.35, p.321-327, 2006.

RICH, K.M. Animal diseases and the cost of compliance with international standards and export markets - The experience of foot-and-mouth disease in the Southern Cone. Washington, D.C.: The World Bank, 2005. 42p.

SAGHAIAN, S.H.; REED, M.R. Consumer reaction to beef safety scares. International Food and Agribusiness Management Review, v.10, p.18-35, 2007.

SASAKI, K.; MITSUMOTO, M. Questionnaire-based study on consumer requirements for beef quality in Japan. Animal Science Journal, v.75, p.369-376, 2004.

SCHNETTLER, B.; RUIZ, D.; SEPÚLVEDA, O. et al. Importance of the country of origin in food consumption in a developing country. Food Quality and Preference, v.19, p.372-382, 2008a.

SCHNETTLER, B.; VIDAL, R.; SILVA, R. et al. Consumer perception of animal welfare and livestock production in the Araucania Region, Chile. Chilean Journal of Agricultural Research, v.68, p.80-93, 2008b.

SCHROEDER, T.C.; TONSOR, G.T.; PENNINGS, J.M.E. et al. Consumer food safety risk perceptions and attitudes: impacts on beef consumption across countries. British E. Journal of Economics Anaysis \& Policy, v.7, p.1-27, 2007.

SCHWÄGELE, F. Traceability from a European perspective. Meat Sciece, v.7, p.164-173, 2005.

SEGRILLO, A. O fim da URSS e a nova Rússia: de Gorbachev ao pós-Yeltsin. Petrópolis: Vozes, 2000. 152p.

SMITH, G.C.; TATUM, J.D.; BELK, K.E. et al. Traceability from a US perspective. Meat Science, v.71, p.174-193, 2005.
SPARLING, D.H.; CASWELL, J.A. Risking market integration without regulatory integration: the case of NAFTA and BSE. Review of Agricultural Economics, v.28, p.212-228, 2006.

SUGIURA, K.; SMITH, G.C. A comparison of the risk of bovine spongiform encephalopathy infectivity in beef from cattle younger than 21 months in Japan with that in beef from the United States as assessed by the carcass maturity score. Journal of Food Protection, v.71, p.802-806, 2008.

TONSOR, G.T.; SCHROEDER, T.C.; FOX, J.A. et al. European preferences for beef steak attributes. Journal of Agricultural Resource Economics, v.30, p.367-380, 2005.

UNITED NATIONS COMMODITY TRADE STATISTICS DATABASE - DESA/UNSD. [2008]. Shortcut query. Available at: $<$ http://comtrade.un.org/db $>$ Accessed on: Aug. 16, 2008.

UNITED STATES DEPARTMENT OF AGRICULTURE - USDA. [2002]. Russian Federation livestock and products annual 2002. Available at: <http://www.fas.usda.gov/gainfiles/200209/ 145783922.pdf $>$ Accessed on: Nov. 5, 2008.

UNITED STATES DEPARTMENT OF AGRICULTURE - USDA. [2004]. World beef overview. Available at: $<\mathrm{http}: / / \mathrm{www}$.fas.usda. gov/dlp2/circular/2004/04-03LP/beefoverview.html> Accessed on: Oct. 14, 2008.

UNITED STATES DEPARTMENT OF AGRICULTURE - USDA. [2007]. Livestock and poultry. World markets and trade. Available at:<http://www.fas.usda.gov/dlp/circular/2007/livestock_poultry_ 11-2007.pdf $>$ Accessed on: May 19, 2008

UNITED STATES DEPARTMENT OF AGRICULTURE - USDA. [2008]. Brazil livestock and products: annual livestock reports. Available at: <http://www.fas.usda.gov/gainfiles/200809/ 146295693.pdf $>$ Accessed on: Mar. 18, 2008.

WORLD BANK. [2008a]. Country and lending groups. Available at: <http://web.worldbank.org/WBSITE/EXTERNAL/ DATASTATISTICS/0, contentMDK:20421402 pagePK:64133150 piPK:64133175 theSitePK:239419,00.html\#Low income> Accessed on: Nov. 2, 2008.

WORLD BANK. [2008b]. Data \& statistics: country groups. Available at: <http://web.worldbank.org/WBSITE/EXTERNAL/ DATASTATISTICS/0,,contentMDK:20421402 pagePK:64133150 piPK:64133175 theSitePK:239419,00.html\#Low_income> Accessed on: Nov. 2, 2008.

WORLD ORGANIZATION FOR ANIMAL HEALTH - WHO [2007]. World Animal Health Information Database (WAHID) Interface. Available at: <http://www.oie.int/wahis/public.php? page $=$ home $>$ Accessed on: Oct. 27, 2008.

WORLD ORGANIZATION FOR ANIMAL HEALTH - WHO. [2008]. Terrestrial animal health code. Available at: $<$ http://www.oie.int/ eng/normes/mcode/en sommaire.htm $>$ Accessed on: Mar. 7, 2008.

ZEPEDA, C.; SALMAN, M.; THIERMANN, A. et al. The role of veterinary epidemiology and veterinary services in complying with the World Trade Organization SPS agreement. Preventive Veterinary Medicine, v.67, p.125-140, 2005. 